\title{
Hurler syndrome (Mucopolysaccharidosis type I)
}

\author{
Reuben Grech, Leo Galvin, Alan O'Hare, Seamus Looby
}

Department of Neuroradiology, Beaumont Hospital, Dublin, Ireland

\section{Correspondence to}

Dr Reuben Grech, reubengrech@yahoo.com
To cite: Grech $R$, Galvin $L$, O'Hare A, et al. BMJ Case Rep Published online: [please include Day Month Year] doi:10.1136/bcr-2012008148

\section{DESCRIPTION}

Hurler syndrome is a rare lysosomal storage disorder with a prevalence of 1 in 100000 . It is caused by a defective IDUA gene which codes for $\alpha-\mathrm{L}$ iduronidase and has an autosomal recessive inheritance. Enzyme deficiency results in accumulation of dermatan and heparan sulfate in multiple tissues which leads to progressive deterioration and eventual death.

The condition manifests with profound intellectual disability, corneal clouding, cardiac disease and characteristic musculoskeletal manifestations. Affected individuals have coarse facial features including a low nasal bridge and excessive hair growth. Additional symptoms include hearing loss, recurrent respiratory infections, 'claw' hand deformities and macroglossia.

Cervical myelopathy results from congenital vertebral anomalies (figure 1) and atlantoaxial subluxation which is seen in up to $38 \%$ of affected individuals. ${ }^{1}$ It can be further aggravated by infiltration of the dura and cervical cord with mucopolysaccharides (figure 2). ${ }^{2}$ The vertebral bodies are characteristically hypoplastic and demonstrate anteroinferior 'beaks'. Inferior vertebral beaking is also seen in achondroplasia, pseudoachondroplasia, congenital hypothyroidism, trisomy 21 and a variety of neuromuscular disorders.

The main laboratory finding is absence of lysosomal enzyme $\alpha$-L-iduronidase activity in peripheral blood leucocytes, cultured fibroblasts and plasma and is considered diagnostic. A positive family history is often present.

Affected individuals often succumb to the condition in the first decade, from respiratory and cardiac complications. Apart from offering symptom relief, enzyme replacement therapy with

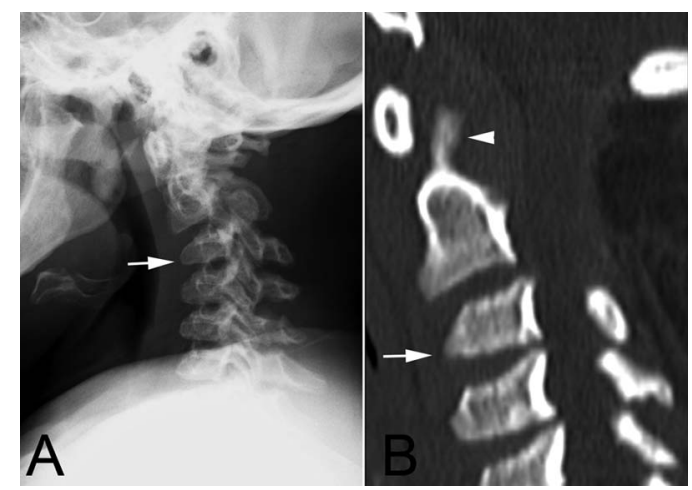

Figure 1 Lateral radiograph (A) and sagittal CT (B) show hypoplastic cervical vertebrae with pathognomonic 'inferior beaking' (arrows). Previous posterior cervical decompression and characteristic hypoplasia of the odontoid process (arrowhead) is seen.

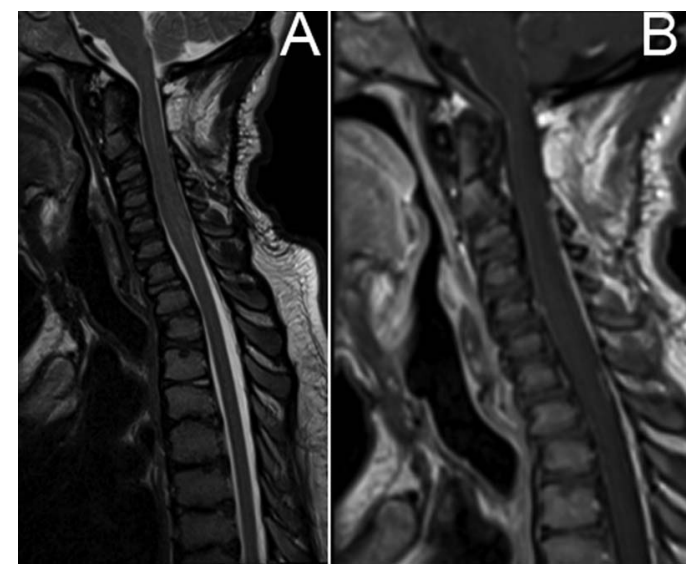

Figure 2 Sagittal T2 (A) and contrast-enhanced T1 (B) sequences show expansion of the cervical cord, with no identifiable mass lesion or syrinx.

laronidase and bone marrow transplantation may also improve life expectancy. ${ }^{3}$ Genetic counselling and testing should be considered for couples with a positive family history.

\section{Learning points}

- Hurler syndrome is a rare autosomal recessive, lysosomal storage disorder.

- Affected individuals demonstrate typical clinical manifestatiosns, and the diagnsosis is confirmed by demonstrating $\alpha$-L-iduronidase deficiency.

- Characteristic radiological findings include inferior vertebral beaking and odontoid hypoplasia.

Competing interests None.

Provenance and peer review Not commissioned; externally pee reviewed.

\section{REFERENCES}

1 Belani KG, et al. Children with mucopolysaccharidosis: perioperative care, morbidity, mortality, and new findings. J Pediatr Surg 1993;28:403-8.

2 Kachur E, Del Maestro R. Mucopolysaccharidoses and spinal cord compression: case report and review of the literature with implications of bone marrow transplantation. Neurosurgery-Baltimore 2000;47:223-9.

3 Kirkpatrick K, Ellwood J, Walker RW. Mucopolysaccharidosis type I (Hurler syndrome) and anesthesia: the impact of bone marrow transplantation, enzyme replacement therapy, and fiberoptic intubation on airway management. Paediatr Anaesth 2012;22:745-51. 
Copyright 2013 BMJ Publishing Group. All rights reserved. For permission to reuse any of this content visit http://group.bmj.com/group/rights-licensing/permissions.

BMJ Case Report Fellows may re-use this article for personal use and teaching without any further permission.

Become a Fellow of BMJ Case Reports today and you can:

- Submit as many cases as you like

- Enjoy fast sympathetic peer review and rapid publication of accepted articles

- Access all the published articles

- Re-use any of the published material for personal use and teaching without further permission

For information on Institutional Fellowships contact consortiasales@bmjgroup.com

Visit casereports.bmj.com for more articles like this and to become a Fellow 